\title{
CLINICAL-RADIOGRAPHIC CORRELATION OF DEGENERATIVE CHANGES OF THE SPINE - SYSTEMATIC REVIEW
}

\author{
CORRELAÇÃO CLÍNICO-RADIOLÓGICA DAS ALTERAÇÕES DEGENERATIVAS \\ DA COLUNA - REVISÃO SISTEMÁTICA \\ CORRELACIÓN CLÍNICO-RADIOLÓGICA DE LOS CAMBIOS DEGENERATIVOS \\ DE LA COLUMNA - REVISIÓN SISTEMÁTICA
}

\author{
Emiliano Neves Vialle¹, Luiz Roberto Gomes Vialle ${ }^{1,2}$, Christiano Esteves Simões ${ }^{3,4}$, Phelipe de Souza Menegaz ${ }^{1,4}$ \\ 1. Pontifícia Universidade Católica do Paraná (PUCPR), Hospital Universitário Cajuru (HUC), Spine Surgery Group, Curitiba, PR, Brazil. \\ 2. Pontifícia Universidade Católica do Paraná (PUCPR), Escola de Medicina, Department of Orthopedics and Traumatology, Curitiba, PR, Brazil. \\ 3. Hospital Felício Rocho, Spine Surgery Group, Belo Horizonte, MG, Brazil. \\ 4. Spine Surgery Fellow, AOSpine Latin America.
}

\begin{abstract}
Systematic review of the literature on the evaluation of images of degenerative changes of the spine and its clinical correlation. A systematic literature review was conducted, and the results evaluated for the presence of clinical correlation, as well as the type of imaging method used. The search terms were "Intervertebral Disc Degeneration", "Intervertebral disc", "Classification", "Anulus fibrosus", "Nucleus pulposus", "Lumbar spine", "Degenerative disc disease", "Degeneration", "Zygapophyseal Joint". We also assessed whether there were inter- and intraobserver agreement in the selected works and possible guidelines regarding the treatment and prognosis of patients. Of the 91 reviewed abstracts, 31 articles were selected that met the inclusion criteria. Six articles were related to the cervical spine, 13 to the lumbar spine and 12 were about changes not related specifically to a single segment of the spine. Articles that determined limiting values considered normal were also included, since variations were considered signs of degeneration or pathology. It was not possible to establish the relationship between the changes identified in imaging and the clinical history of patients, either define treatment and prognosis guidelines.
\end{abstract}

Keywords: Intervertebral disc degeneration; Intervertebral disc; Classification; Spine; Zygapophyseal joint.

\section{RESUMO}

Revisão sistemática da literatura de avaliação por imagem das alterações degenerativas da coluna e sua correlação clínica. A revisão sistemática da literatura foi realizada e seus resultados, avaliados com relação à presença de correlação clínica, assim como o tipo de método de imagem utilizado. Os termos de pesquisa foram "Intervertebral Disc Degeneration", "Intervertebral disc", "Classification", "Anulus fibrosus", "Nucleus pulposus", "Lumbar spine", "Degenerative disc disease", "Degeneration", "Zygapophyseal Joint". Também se avaliou se houve concordância inter e intraobservador nos trabalhos selecionados e possíveis orientações com relação ao tratamento e ao prognóstico dos pacientes. Dos 91 resumos revisados, foram selecionados 31 artigos que satisfizeram os critérios de inclusão. Seis artigos estavam relacionados com a coluna cervical, 13 com a coluna lombar e 12 versavam sobre alterações não relacionadas especificamente com um único segmento da coluna. Os artigos que determinaram valores limítrofes considerados normais também foram incluídos, uma vez que suas variações foram consideradas sinais de degeneração ou patologia. Não foi possível estabelecer a relação entre alterações identificadas nos exames de imagem e a história clínica dos pacientes, tampouco definir orientações de tratamento e prognóstico.

Descritores: Degeneração do disco intervertebral; Disco intervertebral; Classificação; Coluna vertebral; Articulação zigapofisária.

\section{RESUMEN}

Revisión sistemática de la literatura sobre evaluación por imágenes de los cambios degenerativos de la columna y su correlación clínica. Fue realizada una revisión sistemática de la literatura y sus resultados evaluados cuanto a la presencia de correlación clínica, así como al tipo de método de imagen utilizado. Los términos de búsqueda fueron "Intervertebral Disc Degeneration", "Intervertebral disc", "Classification", "Anulus fibrosus", "Nucleus pulposus", "Lumbar spine", "Degenerative disc disease", "Degeneration", "Zygapophyseal Joint". Se evaluó también si había concordancia inter e intraobservador en los trabajos seleccionados, además de las posibles orientaciones en cuanto al tratamiento y al pronóstico de los pacientes. De los 91 resúmenes revisados, treinta y un artículos que cumplieron los criterios de inclusión fueron seleccionados. Seis artículos estaban relacionados con la columna cervical, 13 con la columna lumbar y 12 eran acerca de cambios no relacionados específicamente a un solo segmento de la columna vertebral. También se incluyeron artículos que determinaron valores límites considerados normales, ya que los cambios fueron considerados señales de degeneración o patología. No fue posible establecer la relación entre los cambios identificados en las imágenes y la historia clínica de los pacientes, tampoco definir orientaciones de tratamiento y pronóstico.

Descriptores: Degeneración del disco intervertebral; Disco intervertebral; Clasificación; Columna vertebral; Articulación cigapofisaria. 


\section{INTRODUCTION}

Degenerative changes in the spine are often found in imaging exams, independently of morphological and clinical changes among individuals of the same sex, age, and profession. The principal morphological changes observed in the intervertebral discs and facet joints have been the subject of various descriptions using histological ${ }^{1-9}$ and morphological ${ }^{2,6,8-12}$ methods and especially with the use of imaging methods, such as radiography (X-ray), ${ }^{2,10,13-15}$ computed tomography (CT), ${ }^{6,15-17}$ magnetic resonance imaging (MRI), ${ }^{6,15,18}$ and discography. ${ }^{19}$

The correlation between degenerative changes and the presence of symptoms is the subject of discussion and controversy. The prevalence of lumbar and cervical pain in the adult population and the ease of access to imaging exams create an often unfounded impression of disease. However, we lack the tools to enable us to distinguish the natural changes of the aging process from changes associated with pain and disability.

The need to classify the degeneration by grades is due to the fact that these systems can clarify doubts about the relationship between morphology and functional parameters, or between instability and intradiscal pressure, or be used to correlate the different morphological changes encountered. ${ }^{20}$

Several descriptions of disc degeneration are available in the literature, however these changes need to be quantified, especially for research reasons. ${ }^{21}$ An analysis of existing systems reveals different methods for grading the changes and possible correlations between lesions and symptoms, though there is currently no consensus.

Thus, the objective of the authors is to conduct a systematic review of the pertinent literature in search of objective evaluations of disc and facet joint degeneration, comparing their advantages and disadvantages, as well as highlighting their possible clinical correlations. We also intend to define a possible application of these evaluations to the decision-making process for the treatment of degenerative spine changes.

\section{METHOD}

A bibliographical investigation of the Medline, Embase, FirstBook, Web of Science, Google Scholar data bases and the Cochrane systematic reviews was performed using the search terms "Intervertebral Disc Degeneration", "Intervertebral disc", "Classification", "Annulus fibrosus", "Nucleus pulposus", "Lumbar spine", "Degenerative disc disease", "Degeneration", and "Zygapophyseal Joint". Articles published during the period between 1945 and 2012 in English, French, German, Italian, Portuguese, and Spanish were included. We selected abstracts that present a description of degenerative spinal changes identified and quantified by imaging methods, in addition to studies that associate these changes with some severity scoring or grading system.

For the initial selection, the exclusion criteria applied were the detection of subjective and undetailed descriptions, metric units or scores that did not permit the degenerative changes to be quantified, articles in a language other than those cited above, and publications without an abstract available for consultation.

All the abstracts were first evaluated by three independent reviewers and, once compliance with the criteria was confirmed, complete versions of the selected articles were obtained. A critical reading of these followed and their respective references were researched for additional data, with the intention of refining the initial selection. Any disagreements about the selection of the articles were resolved by consensus among the three reviewers. All the articles used in this systematic review were categorized by level of evidence according to the scale of evidence of Sackett et al. ${ }^{22}$ This study is a systematic review of the literature and does not involve patients, so the approval of the Institutional Review Board was not required.

\section{RESULTS}

In the initial search, we found 681 articles and selected 92 of them using the abstracts. Of these, 31 satisfied the inclusion criteria. Of the 61 works excluded, four had no available abstract, eight were in languages other than those previously cited, and 49 lacked a quantified and objective description of vertebral degeneration.

Of the 31 articles selected, six included cervical measurements (four with values considered normal and two with degenerative changes), 13 lumbar measurements (eight indicating degenerative changes and five describing normal values), and 12 with changes not specifically related to a defined spinal segment, such as measurements related to the sacro-pelvic region, which can directly impact degeneration of spinal segments. (Figure 1)

The four articles with descriptions of cervical measurements ${ }^{23-26}$ identified normal values for parameters such as angulations and amplitudes of movement. These values were correlated with degenerative conditions, situations that lead to possible instability, pain, and neurological changes. (Table 1)

Three articles ${ }^{27-29}$ defined the normal values for the sacro-pelvic region, where a correlation with sagittal imbalance, the presence of a propensity towards spondylolisthesis and its complications (such as difficulty walking), neurological changes, and pain were demonstrated. (Table 2)

Roussouly et al. ${ }^{30}$ grouped the most common changes in sagittal alignment, the sacrum, and the pelvis into four groups, suggesting that for each group there would be a different disposition towards degeneration of the lumbar spine, whether facetary, discal, or a predisposition towards spondylolisthesis. (Figure 2) The authors also defined a subgroup that was considered normal and with less propensity towards degeneration.

Among all the articles reviewed, a description and respective assessment of the degenerative changes in the radiographs was found in six of them. ${ }^{21,31-35}$ It is worth noting the use of the same parameters for degeneration - the presence of osteophytes, the loss

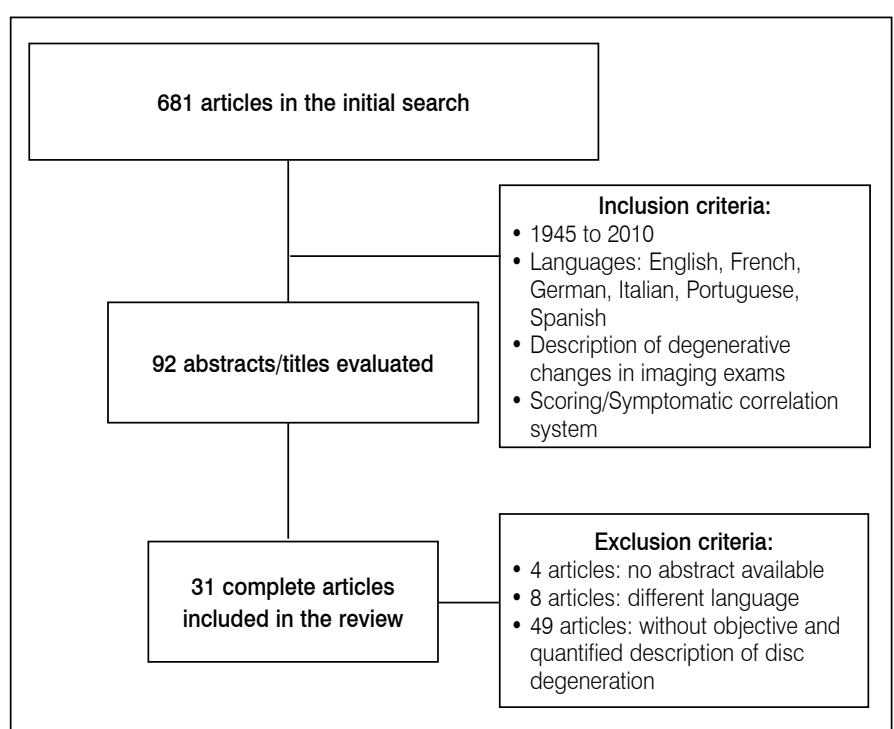

Figure 1. Flowchart describing the search strategy that resulting in 31 selected articles.

Table 1. Cervical Measurements.

\begin{tabular}{c|c|c|c}
\hline Author & Parameters evaluated & $\begin{array}{c}\text { Evaluation } \\
\text { method }\end{array}$ & $\begin{array}{c}\text { Clinical } \\
\text { correlation }\end{array}$ \\
\hline Czervionke, 198823 & $\begin{array}{c}\text { Diameter of the cervical } \\
\text { foramen }\end{array}$ & MRI & Yes \\
\hline Uchida, 200924 & $\begin{array}{c}\text { Cervical kyphosis and } \\
\text { segmental instability } \\
\text { associated with } \\
\text { myelopathy }\end{array}$ & X-RAY & Yes \\
\hline Dvorak, 1992 & $\begin{array}{c}\text { Amplitude of cervical } \\
\text { movement }\end{array}$ & X-RAY & Yes \\
\hline Pavlov, 198726 & Diameter of vertebral canal & X-RAY & Yes \\
\hline
\end{tabular}


Table 2. Sacro-pelvic measurements.

\begin{tabular}{c|c|c|c}
\hline Author & Parameters evaluated & $\begin{array}{c}\text { Evaluation } \\
\text { method }\end{array}$ & $\begin{array}{c}\text { Clinical } \\
\text { correlation }\end{array}$ \\
\hline Lafage, 200927 & $\begin{array}{c}\text { Inclinations of the pelvis } \\
\text { and trunk (in deformities) }\end{array}$ & X-RAY & Yes \\
\hline Lazennec, 200028 & Sagittal alignment & X-RAY & Yes \\
\hline Yoshimoto, 200529 & Sagittal alignment & X-RAY & Yes \\
\hline X-RAY: radiographs.
\end{tabular}
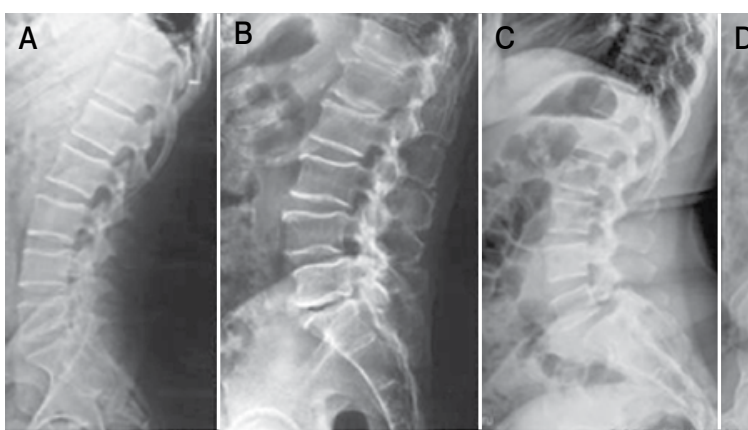

Figure 2. Roussouly classification. (Key: A = Roussouly type I, B= type II, $\mathrm{C}=$ type III, D= type IV).

of disc height, and subchondral sclerosis - qualified in such a way as to be used for the composition of grading schemes regarding the severity of the clinical profile presented by the patient. (Table 3)

Pathria et al. ${ }^{36}$ developed a grading system based on degenerative facet changes identified in oblique radiographs and CT. Weishaupt et al. ${ }^{37}$ correlated changes in CT with those found in MRI, using the parameters of facet joint space, articular hypertrophy, and the presence of osteophytes to define their grades. Using MRI, Stadnik et al. ${ }^{38}$ identified degenerative changes, describing the concept as High Intensity Zones (HIZ), positively correlated with disc rupture.

Three other studies proposed grading systems using changes found in MRI, ${ }^{39-41}$ with the methodological particularities between them. Modic et al. ${ }^{39}$ evaluated changes in the vertebral plateau, in both T1- and T2-weighted sequences and Miyazaki et al. ${ }^{41}$ also addressed degenerative cervical changes in T2. Adams et al., ${ }^{19}$ in turn, described a classification of degeneration using image patterns found following discography exams, outlining the changes encountered and correlating them with the different evolutionary stages of disc degeneration. (Table 4).

In terms of the grading systems found in the review, (Table 5) we confirmed a disparity in the number of evolutionary stages of disc generation used, ranging from three to five. Additionally, the evaluation methodologies applied were not standardized, given that some studies used the presence or absence of changes as a scoring criterion, while others attributed values to them based mainly on their size and location. In addition, some of the systems proposed started their grading scales with the lowest intensity encountered, while others applied the inverse, with the most serious stage first.

The final results published also presented differences in the definitions of "the absence of changes", being categorized as Grade 0 in some articles and as Grade 1 in others. It should be noted that studies using subjective terms like "mild", "moderate", and "initial", among others, without specific criteria based on measurements or standardized images, were excluded from the results presented because they did not permit inter- and intraobserver reproducibility. No studies exclusively describing thoracic spine changes were found.

\section{DISCUSSION}

The large number of studies found in the literature demonstrates the need to identify the degenerative changes found in the spine, quantify them, and correlate them with the clinical profile, the treatment, and the prognosis of the patients. However, it also demonstrates the lack of a precise evaluation method that is directly linked to the clinical profile of the patient. Many times, changes considered to be advanced
Table 3. Disc degeneration.

\begin{tabular}{c|c|c|c}
\hline Author & Parameters evaluated & $\begin{array}{c}\text { Evaluation } \\
\text { method }\end{array}$ & $\begin{array}{c}\text { Clinical } \\
\text { correlation }\end{array}$ \\
\hline Wilke, $2006^{21}$ & Lumbar disc degeneration & X-RAY & NT \\
\hline Kellgren, $1963^{31}$ & Cervical disc degeneration & X-RAY & NT \\
\hline Cote, $1997^{32}$ & $\begin{array}{c}\text { Facet and disc degeneration } \\
\text { and cervical sagittal curvature }\end{array}$ & X-RAY & NT \\
\hline Mimura, 1994 33 & Lumbar disc degeneration & X-RAY & NT \\
\hline Lane, $1993^{34}$ & Lumbar disc degeneration & X-RAY & NT \\
\hline Kettle, $2006^{35}$ & Cervical disc degeneration & X-RAY & NT \\
\hline
\end{tabular}

X-RAY: Radiographs; NT: not tested.

Table 4. Degeneration evaluated by other imaging methods.

\begin{tabular}{c|c|c|c}
\hline Author & Parameters evaluated & $\begin{array}{c}\text { Evaluation } \\
\text { method }\end{array}$ & $\begin{array}{c}\text { Clinical } \\
\text { correlation }\end{array}$ \\
\hline Pathria, 198736 & Facet degeneration & $\begin{array}{c}\text { X-RAY and } \\
\text { CT }\end{array}$ & NT \\
\hline Weishaupt, 199937 & Facet degeneration & CT and MRI & NT \\
\hline Stadnik, 1998 & $\begin{array}{c}\text { Annular lesion and disc } \\
\text { herniation }\end{array}$ & MRI & Weak \\
\hline Modic, 1988 & $\begin{array}{c}\text { Change in the vertebral } \\
\text { plateau }\end{array}$ & MRI & Weak \\
\hline Pfirrmann, 200440 & $\begin{array}{c}\text { Morphology of the } \\
\text { intervertebral disc }\end{array}$ & MRI & NT \\
\hline Miyazaki, 2008 & Cervical intervertebral disc & MRI & NT \\
\hline Adams, 1986 & Disc degeneration & Discography & Weak \\
\hline MRI: Magnetic resonance; X-RAY: Radiographs; CT: computed tomography; NT: not tested.
\end{tabular}

Table 5. Articles published with their own method for grading degeneration.

\begin{tabular}{|c|c|c|}
\hline Changes evaluated & Author & Method used \\
\hline \multicolumn{3}{|l|}{ Cervical } \\
\hline $\begin{array}{l}\text { Osteophytes, disc height, and } \\
\text { sclerosis of the vertebral plateau }\end{array}$ & Kelgren $1963^{31}$ & X-RAY Profile \\
\hline $\begin{array}{l}\text { Osteophytes and changes in the } \\
\text { articular apophyses }\end{array}$ & Kelgren $1963^{31}$ & X-RAY Profile \\
\hline $\begin{array}{c}\text { Loss of height, osteophytic formation, } \\
\text { and diffuse sclerosis }\end{array}$ & Wilke $2006^{21}$ & X-RAY Profile \\
\hline Intervertebral disc degeneration & Miyazaki $2008^{41}$ & MRI \\
\hline $\begin{array}{l}\text { Kyphosis and segmental instability } \\
\text { associated with myelopathy }\end{array}$ & Uchida $2009^{24}$ & X-RAY Profile \\
\hline \multicolumn{3}{|l|}{ Lumbar } \\
\hline Lumbar disc degeneration & Adams $1986^{19}$ & Discography \\
\hline $\begin{array}{l}\text { Facet degeneration } \\
\end{array}$ & Pathria $1987^{36}$ & X-RAY Oblique \\
\hline $\begin{array}{c}\text { Bone marrow changes located in the } \\
\text { vertebral body }\end{array}$ & Modic $1988^{42}$ & MRI \\
\hline $\begin{array}{c}\text { Articular narrowing, osteophytes and } \\
\text { subchondral sclerosis }\end{array}$ & Lane $1993^{34}$ & X-RAY Profile \\
\hline $\begin{array}{l}\text { Disc height, osteophytes, and } \\
\text { subchondral sclerosis }\end{array}$ & Mimura $1994^{33}$ & $\begin{array}{c}\text { X-RAY } \\
\text { (AP and Profile) }\end{array}$ \\
\hline Facet degeneration & $\begin{array}{c}\text { Weishaupt } \\
1999^{37}\end{array}$ & $\mathrm{CT}+\mathrm{MRI}$ \\
\hline Disc degeneration & Pfirrmann $2001^{49}$ & MRI \\
\hline $\begin{array}{c}\text { Loss of height, osteophytic formation, } \\
\text { and diffuse sclerosis }\end{array}$ & Wilke $2006^{21}$ & $\begin{array}{l}\text { X-RAY (AP and } \\
\text { Profile) }\end{array}$ \\
\hline
\end{tabular}

X-RAY: radiography; MRI: magnetic resonance; CT: computed tomography.

present less important symptoms in certain patients as compared to others with fewer changes in the image exams.

In another attempt at standardization based on clinical correlation, Modic et al. ${ }^{42}$ identified signs of discal fissure (HIZ) in $56 \%$ of the asymptomatic individuals in MRI with and without contrast and this sign was considered to be a weak predictor of the occurrence of lumbar pain.

A grading system needs to meet several basic criteria to be considered valid. The score needs to be the same regardless of the examiner's experience and must reflect the real grade of degeneration. ${ }^{21}$ Most of the studies base their results on subjective evaluations, using criteria such as "moderate" or "severe" or "small" or "large". ${ }^{13,34,43-45}$

Most of the studies adopt an evaluation of the changes through radiographic exams. Wilke et al. ${ }^{21}$ propose three advantages in relation to this methodology: they are less invasive than other exams; they 
are simpler; they are less expensive and often available because of previous diagnostic studies or for patient follow-up.

Even with the heightened interest in this topic, we confirmed that there is a lack of consensus around the criteria evaluated in degenerative changes. Most authors verified radiographic exams in anteroposterior (AP) and lateral (L) views, to look for the presence of osteophytes and subchondral sclerosis, as well as to assess disc height and the dimensions and positions of the osteophytes.

Frobin et al. ${ }^{45}$ collaborated in an important way by defining normal disc height values, later being able to apply them as a populational reference. For this reason, in our study the patients were categorized into only three grades of degeneration - normal, mild, and moderate/severe. In an optimization process, Mimura et al. ${ }^{33}$ (Table 6) proposed a new system, also based on spinal radiographs. For this, they evaluated disc height (divided into four different anatomical sections), the presence of osteophytes and their size, and the presence of vertebral sclerosis in one or both plateaus. The main objective of the grading system was to investigate the effects of degeneration on the flexibility of the spine, but there is no description of clinical tests to validate it.

Wilke et al. ${ }^{21}$ described a similar grading system for lumbar changes, (Table 7 ) in which the criteria were scored individually and the final grade of degeneration was determined by summing these three items. Interobserver agreement, which according to the Kappa coefficient was 0.714 points indicating substantial agreement, was tested among different evaluators. The authors concluded the study, calling the proposed system "almost" objective, valid, and reliable, but they noted that the true grade of degeneration tends to be underestimated, and that there are significant differences in evaluations depending on the experience of the evaluator.

Lane et al. ${ }^{34}$ (Table 8) evaluated radiographs in lateral view only, addressing the narrowing of the articular space, the presence of osteophytes, and sclerosis of the vertebral plateaus. The interobserver validity analysis, based on the assessments of three evaluators considered to be experienced, yielded Kappa coefficients of 0.93 for reduction of the articular space, 0.91 for the osteophytes, and 0.93 for the final result. However, in relation to sclerosis of the vertebral plateau, a Kappa coefficient of only 0.55 was obtained, indicating weak agreement between the evaluators for the item in question.

Kettler et al. ${ }^{35}$ proposed a new grading system for cervical degeneration, similar to the one developed for the lumbar spine by Wilke et al. ${ }^{21}$ They evaluated the loss of disc height and the presence of osteophytes and subchondral sclerosis, and they compared the radiographic scores with the structural changes found macroscopically after dissecting the pieces. The value of the Kappa coefficient found was 0.688 . Among all the criteria evaluated, the single variable with the highest agreement was the presence and the size of the osteophytes. However, when the presence of subchondral sclerosis was evaluated, an extremely low agreement was found, corroborating the results of other studies analyzed. The authors consider the classification to be valid, also noting that in cases of degeneration of the cervical spine there is a tendency to underestimate the radiographic changes present, especially by less experienced examiners.

Pfirrmann et al. ${ }^{49}$ graded disc degeneration using T2-weighted $\mathrm{MRI}$ images, verifying the intensity of the signal in correlation with disc height, in addition to analyzing the structure of the intervertebral disc and the distinction between the nucleus and the annulus fibrosus. For

Table 6. Grading system of Mimura et al.

\begin{tabular}{|c|c|c|c|}
\hline $\begin{array}{l}\text { Loss of disc height } \\
\text { (\% of adjacent disc) }\end{array}$ & $\begin{array}{l}\text { Osteophytic } \\
\text { formation* }\end{array}$ & $\begin{array}{c}\text { Sclerosis of } \\
\text { the vertebral } \\
\text { plateaus }\end{array}$ & $\begin{array}{c}\text { Results } \\
\text { (sum of points) }\end{array}$ \\
\hline $\begin{array}{c}\text { O = Normal } \\
\text { 1= Mild }(>75 \%) \\
2=\text { Moderate }(>50 \%) \\
\text { 3= Severe }(>25 \%) \\
\text { 4= Very Severe } \\
(<25 \%)\end{array}$ & $\begin{array}{c}0=0 \text { Points } \\
1=1-4 \text { Points } \\
2=5-8 \text { Points } \\
3=9-12 \text { Points } \\
4=13-16 \text { Points }\end{array}$ & $\begin{array}{c}0=\text { Absent } \\
1=\text { One plateau } \\
\text { (above or below) } \\
2=\text { Both plateaus }\end{array}$ & $\begin{array}{c}\text { Grade I: } 0 \text { to } 1.5 \\
\text { Grade II: } 2.0-3.5 \\
\text { Grade III: } 4.0-6.0 \\
\text { Grade IV }>6.0\end{array}$ \\
\hline
\end{tabular}

${ }^{*}=$ sum of the points of the eight extremities; $<3 \mathrm{~mm}=1$ point, $>3 \mathrm{~mm}=2$ points.
Table 7. Lumbar spine grading system of Wilke et al. ${ }^{21}$

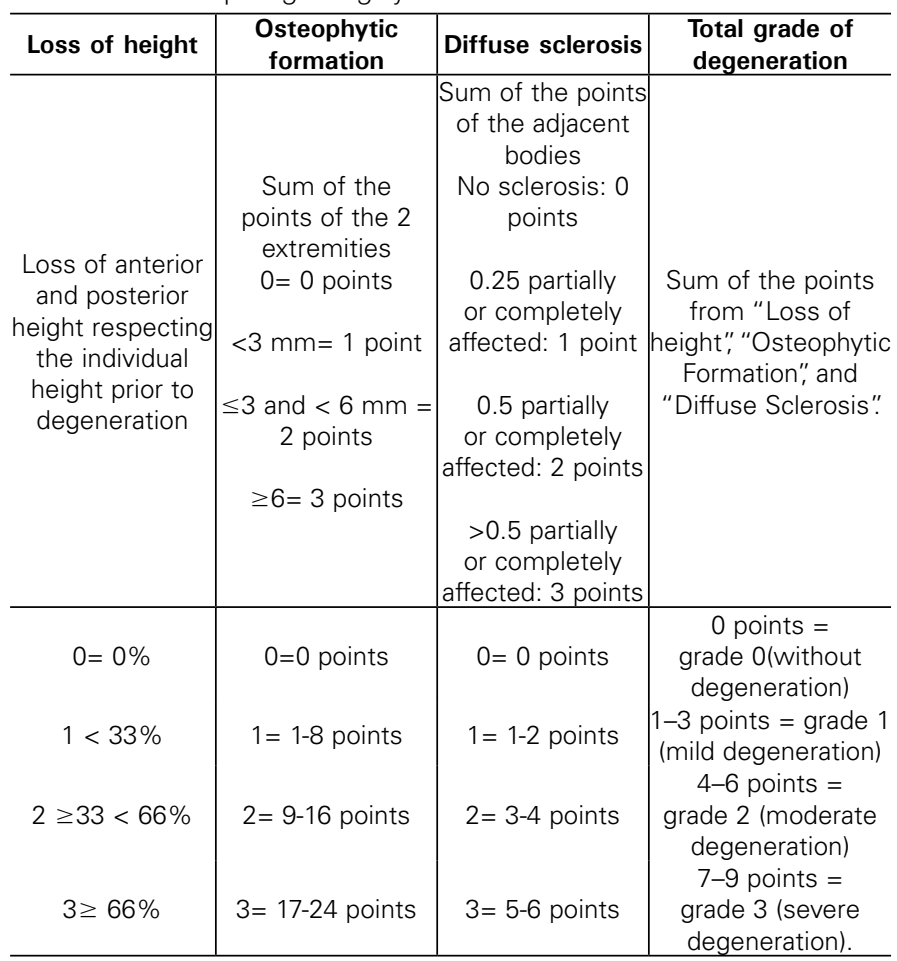

Table 8. Grading system of Lane et al. ${ }^{34}$

\begin{tabular}{|c|c|c|c|}
\hline $\begin{array}{l}\text { Narrowing } \\
\text { of articular } \\
\text { space }\end{array}$ & $\begin{array}{l}\text { Anterior and } \\
\text { posterior } \\
\text { osteophytes }\end{array}$ & $\begin{array}{l}\text { Sclerosis } \\
\text { of the } \\
\text { vertebral } \\
\text { plateau }\end{array}$ & $\begin{array}{l}\text { Grading of the } \\
\text { degeneration }\end{array}$ \\
\hline $\begin{array}{l}0=\text { None } \\
1=\text { Mild }\end{array}$ & $\begin{array}{l}0=\text { None } \\
1=\text { Small }\end{array}$ & $\begin{array}{c}0=\text { None } \\
1=\text { Present }\end{array}$ & $\begin{array}{c}\text { Grade } 0=\text { Normal } \\
\text { articulation } \\
\text { (0 for osteophytes and } \\
\text { narrowing) }\end{array}$ \\
\hline $\begin{array}{l}2=\text { Moderate } \\
3=\text { Severe } \\
\text { (total loss) }\end{array}$ & $\begin{array}{c}\text { 2= Moderate } \\
\text { 3= Large }\end{array}$ & & $\begin{array}{c}\text { Grade I= Moderate } \\
\text { (1) narrowing or mild (1) } \\
\text { osteophytes }\end{array}$ \\
\hline & & & $\begin{array}{c}\text { Grade II = Moderate- } \\
\text { Severe (2-3) narrowing } \\
\text { and/or moderate to } \\
\text { severe } \\
\text { (2-3) osteophytes }\end{array}$ \\
\hline
\end{tabular}

this proposed method of analysis, the values of the Kappa coefficient ranged from 0.74 to 0.81 . Theses higher indices, as compared to those obtained from the radiographic classifications, suggest that the items evaluated via MRI and the intensity of the signal may be more objective than the bone changes found in radiographs.

Regarding the reliability of the validation studies of the proposed grading systems, Kovacs et al. ${ }^{50}$ suggested that, in various cases, high agreement is due to the reduced number of observers and to the fact that they belong to the same hospital service. In their study, seven observers at different levels of experience in spine surgery from three distinct services evaluated the imaging exams of the spine applying the grading proposed by Pfirrmann and found an intraobserver agreement of 0.601 (Kappa ranging from 0.00 to 0.99 ) and an interobserver agreement of 0.219 (Kappa ranging from 0.024 to 0.59), demonstrating little interobserver agreement for this classification.

In the same study, Kovacs et al. ${ }^{50}$ also assessed the agreement between the Modic grading system and the presence of the HIZ signal in MRI. High inter- and intraobserver agreements were identified, but the literature shows that the presence of these changes is a weak predictor of future low back pain, conferring little prognostic value. Today we 
know that HIZ can be present in the imaging exams of $30 \%$ to $56 \%$ of asymptomatic individuals. ${ }^{37,38}$

Considering the studies evaluated, it is possible that, although the criteria for the definition of disc degeneration have been established, this can only be inferred through comparisons of the measurements of disc height at different times of day and at different patient ages, since significant variations have been described even during a single day. ${ }^{45-47}$ Other items evaluated, such as the presence and size of the osteophytes, while lending a higher degree of objectivity to the evaluation, reflect significant variations among observers in the literature.

\section{CONCLUSION}

Several grading systems involving geometric or descriptive measurements of changes related to disc and facet degeneration are available in the literature, however, there is great disparity in terms of the criteria applied, the results presented, and the possible clinical correlations. No single system was identified in this review that can define prognosis or guide treatments. It was also confirmed that most of the scales proposed have not been tested for their validity or inter- and intraobserver agreement. A significant disparity remains in the evaluation methodologies, both for the most efficient imaging exam, taking cost versus benefit into account, and for the ideal criteria to be evaluated.

Thus, to date, according to the available literature, future research is needed to define the ideal system.

All the authors declare that there are no potential conflicts of interest regarding this article.

CONTRIBUTIONS OF THE AUTHORS: Each author made significant individual contributions to the development of the manuscript. ENV participated in the development of the research project, the review of the literature, and the preparation of the manuscript. LRGV participated in the review of the manuscript. CES and PSM participated in the literature review and the preparation of the manuscript.

\section{REFERENCES}

1. Boos N, Weissbach S, Rohrbach H, Weiler C, Spratt KF, Nerlich AG. Classification of agerelated changes in lumbar intervertebral discs: 2002 Volvo Award in basic science. Spine (Phila Pa 1976). 2002;27(23):2631-44

2. Collins DH. The pathology of articular and spinal diseases. London: Edward Arnold \& Lamp; 1949

3. Coventry MB, Ghormley RK, Kernohan JW. The intervertebral disc: Its microscopic anatomy and pathology: Part I. Anatomy, development and pathology. J Bone Joint Surg. 1945:27:105-12.

4. Coventry MB, Ghormley RK, Kernohan JW. The intervertebral disc: Its microscopic anatomy and pathology: Part II. Changes in the intervertebral disc concomitant with age. J Bone Joint Surg. 1945;27:233-47.

5. Eisenstein SM, Parry CR. The lumbar facet arthrosis syndrome. Clinical presentation and articular surface changes. J Bone Joint Surg Br. 1987;69(1):3-7.

6. Fletcher G, Haughton VM, Ho KC, Yu SW. Age-related changes in the cervical facet joints: studies with cryomicrotomy, MR, and CT. AJR Am J Roentgenol. 1990:154(4):817-20.

7. Hirsch. Some morphological changes in the cervical spine during ageing. In: Hirsch $C$, Zotterman Y, editors. Cervical pain. New York: Pergamon Press; 1972. p. 21-32.

8. Töndury $G$. The behaviour of the cervical discs during life. In: Hirsch C, Zotterman Y, editors. Cervical pain. New York: Pergamon Press; 1972.p. 59-66.

9. Vernon-Roberts B, Pirie CJ. Degenerative changes in the intervertebral discs of the lumbar spine and their sequelae. Rheumatol Rehabil. 1977;16(1):13-21.

10. Friberg $S$, Hirsch $C$. Anatomical and clinical studies on lumbar disc degeneration. ActaOrthop Scand. 1949;19(2):222-42.

11. Macnab I. Cervical spondylosis. ClinOrthopRelat Res. 1975;(109):69-77.

12. Swanepoel MW, Adams LM, Smeathers JE. Human lumbar apophyseal joint damage and intervertebral disc degeneration. Ann Rheum Dis. 1995;54(3):182-8.

13. Kellgren JH, Lawrence JS. Rheumatism in miners. II. X-ray study. Br J Ind Med. 1952;9(3):197-207.

14. Kellgren JH, Lawrence JS. Radiological assessment of osteo-arthrosis. Ann Rheum Dis. 1957;16(4):494-502.

15. Resnick D. Degenerative diseases of the vertebral column. Radiology. 1985;156(1):3-14.

16. Butler D, Trafimow JH, Andersson GB, McNeill TW, Huckman MS. Discs degenerate before facets. Spine (Phila Pa 1976). 1990;15(2):111-3

17. Wybier M. Imaging of lumbar degenerative changes involving structures other than disk space. Radiol Clin North Am. 2001;39(1):101-14.

18. Yu S, Haughton VM, Sether LA, Ho KC, Wagner M. Criteria for classifying normal and degenerated lumbar intervertebral disks. Radiology. 1989;170(2):523-6.

19. Adams MA, Dolan P, Hutton WC. The stages of disc degeneration as revealed by discograms. J Bone Joint Surg Br. 1986:68(1):36-41.

20. Kettler A, Wilke HJ. Review of existing grading systems for cervical or lumbar disc and facet joint degeneration. Eur Spine J. 2006;15(6):705-18.

21. Wilke HJ, Rohlmann F, Neidlinger-Wilke C, Werner K, Claes L, Kettler A. Validity and interobserver agreement of a new radiographic grading system for intervertebral disc degeneration: Part I. Lumbar spine. Eur Spine J. 2006;15(6):720-30.

22. Sackett DL, Straus SE, Richardson WS, RosenbergW, Haynes RB. Evidence-based medicine: how to practice and teach EBM. 2nd ed. Edinburgh: Churchill- Livingstone; 2000.

23. Czervionke LF, Daniels DL, Ho PS, Yu SW, Pech P, Strandt J, et al. Cervical neural foramina: correlative anatomic and MR imaging study. Radiology. 1988;169(3):753-9.

24. Uchida K, Nakajima H, Sato R, YayamaT, Mwaka ES, Kobayashi S, Baba H. Cervical spondylotic myelopathy associated with kyphosis or sagittal sigmoid alignment: outcome after anterior or posterior decompression. J Neurosurg Spine. 2009;11(5):521-8.

25. Dvorak J, Antinnes JA, Panjabi M, Loustalot D, Bonomo M. Age and gender related normal motion of the cervical spine. Spine (Phila Pa 1976). 1992;17(Suppl 10):S393-8.

26. Pavlov H, Torg JS, Robie B, Jahre C. Cervical spinal stenosis: determination with vertebral body ratio method. Radiology. 1987;164(3):771-5.

27. Lafage V, Schwab F, Patel A, Hawkinson N, Farcy JP. Pelvic tilt and truncal inclination: two key radiographic parameters in the setting of adults with spinal deformity. Spine (Phila Pa 1976). 2009:34(17):E599-606

28. Lazennec JY, Ramaré S, Arafati N, Laudet CG, Gorin M, Roger B, et al. Sagittal alignment in lumbosacral fusion: relations between radiological parameters and pain. Eur Spine $J$ 2000;9(1):47-55
29. Yoshimoto H, Sato S, MasudaT, Kanno T, Shundo M, HyakumachiT, et al.Spinopelvic alignment in patients with osteoarthrosis of the hip: a radiographic comparison to patients with low back pain. Spine (Phila Pa 1976). 2005;30(14):1650-7.

30. Roussouly P, Gollogly S, Berthonnaud E, Dimnet J. Classification of the normal variation in the sagittal alignment of the human lumbar spine and pelvis in the standing position. Spine (Phila Pa 1976). 2005:30(3):346-53.

31. Kellgren JH, Lawrence JS, editors. The epidemiology of chronic rheumatism: atlas of standard radiographs of arthritis. Oxford: Blackwell Scientific; 1963.

32. Côté P, Cassidy JD, Yong-Hing K, Sibley J, Loewy J. Apophysial joint degeneration, disc degeneration, and sagittal curve of the cervical spine. Can they be measured reliably on radiographs? Spine (Phila Pa 1976). 1997:22(8):859-64

33. Mimura M, Panjabi MM, Oxland TR, Crisco JJ, Yamamoto I, Vasavada A. Disc degeneration affects the multidirectional flexibility of the lumbar spine. Spine (Phila Pa 1976). 1994;19(12):1371-80

34. Lane NE, Nevitt MC, Genant HK, Hochberg MC. Reliability of new indices of radiographic osteoarthritis of the hand and hip and lumbar disc degeneration. J Rheumatol. 1993;20(11):1911-8.

35. Kettler A, Rohlmann F, Neidlinger-Wilke C, Werner K, Claes L, Wilke HJ. Validity and interobserver agreement of a new radiographic grading system for intervertebral disc degeneration: Part II. Cervical spine. Eur Spine J. 2006;15(6):732-41.

36. Pathria M, Sartoris DJ, Resnick D. Osteoarthritis of the facet joints: accuracy of oblique radiographic assessment. Radiology. 1987;164(1):227-30.

37. Weishaupt D, Zanetti M, Boos N, Hodler J. MR imaging and CT in osteoarthritis of the lumbar facet joints. Skeletal Radiol. 1999:28(4):215-9.

38. StadnikTW, Lee RR, Coen HL, Neirynck EC, Buisseret TS, Osteaux MJ. Annular tears and disk herniation: prevalence and contrast enhancement on MR images in the absence of low back pain or sciatica. Radiology. 1998;206(1):49-55

39. Modic MT, Steinberg PM, Ross JS, Masaryk TJ, Carter JR. Degenerative disk disease: assessment of changes in vertebral body marrow with MR imaging. Radiology. 1988:166(1 Pt 1):193-9

40. Pfirrmann CW, Dora C, Schmid MR, Zanetti M, Hodler J, Boos N. MR image-based grading of lumbar nerve root compromise due to disk herniation: reliability study with surgical correlation. Radiology. 2004;230(2):583-8

41. Miyazaki M, Hong SW, Yoon SH, Morishita Y, Wang JC. Reliability of a magnetic resonance imaging-based grading system for cervical intervertebral disc degeneration. J Spinal Disord Tech. 2008:21(4):288-92

42. Modic MT, Ross JS, Obuchowski NA, Browning KH, Cianflocco AJ, Mazanec DJ. Contrast-enhanced MR imaging in acute lumbar radiculopathy: a pilot study of the natural history. Radiology. 1995;195(2):429-35

43. Brooker AE, Barter RW. Cervical spondylosis. A clinical study with comparative radiology. Brain. 1965;88(5):925-36

44. Gordon SJ, Yang KH, Mayer PJ, Mace AH Jr, Kish VL, Radin EL. Mechanism of disc rupture. A preliminary report. Spine (Phila Pa 1976). 1991:16(4):450-6.

45. Frobin W, Brinckmann P, Biggemann M, Tillotson M, Burton K. Precision measurement of disc height, vertebral height and sagittal plane displacement from lateral radiographic views of the lumbar spine. Clin Biomech (Bristol, Avon). 1997;12(Suppl 1):S1-S63.

46. Althoff I, Brinckmann P, Frobin W, Sandover J, Burton K. An improved method of stature measurement for quantitative determination of spinal loading. Application to sitting postures and whole body vibration. Spine (Phila Pa 1976). 1992:17(6):682-93.

47. Botsford DJ, Esses SI, Ogilvie-Harris DJ. In vivo diurnal variation in intervertebral disc volume and morphology. Spine (Phila Pa 1976). 1994;19(8):935-40.

48. Roberts N, Hogg D, Whitehouse GH, Dangerfield P. Quantitative analysis of diurnal variation in volume and water content of lumbar intervertebral discs. Clin Anat. 1998;11(1):1-8

49. Pfirrmann CW, Metzdorf A, Zanetti M, Hodler J, Boos N. Magnetic resonance classification of lumbar intervertebral disc degeneration. Spine (Phila Pa 1976). 2001:26(17):1873-8.

50. Kovacs FM, Royuela A, Jensen TS, Estremera A, Amengual G, Muriel A, et al. Agreement in the interpretation of magnetic resonance images of the lumbar spine. Acta Radiol. 2009;50(5):497-506 